\title{
Considerations on the dimensioning of columns with dimensions less than that established by NBR 6118 (ABNT, 2014)
}

Considerações sobre o dimensionamento de pilares com dimensões inferiores a estabelecida pela NBR 6118 (ABNT, 2014)

Consideraciones sobre el dimensionamiento de pilares con dimensiones inferiores a las establecidas por NBR 6118 (ABNT, 2014)

Renan Gustavo Pacheco Soares

ORCID: https://orcid.org/0000-0002-6366-9663

Universidade Federal de Pernambuco, Brazil E-mail: renangpsoares@hotmail.com

Gustavo Gutierrez de Oliveira Rodrigues

ORCID: https://orcid.org/0000-0001-8617-0120

Universidade Regional de Blumenau, Brazil

E-mail: gustavogutierrez01@hotmail.com

Erivan Mendes da Paz

ORCID: https://orcid.org/0000-0003-3477-9318 Autarquia do Ensino Superior de Garanhuns, Brazil E-mail: erywan2012@hotmail.com

Carla Renata Xavier Pacheco

ORCID: https://orcid.org/0000-0003-0064-9339 Autarquia do Ensino Superior de Garanhuns, Brazil E-mail: carla_renatax@hotmail.com

Lyneker Souza de Moura

ORCID: https://orcid.org/0000-0002-9343-6916 Universidade Federal de Pernambuco, Brazil E-mail: lyneker@gmail.com

Kaike Manoel Barros do Nascimento ORCID: https://orcid.org/0000-0002-8127-3005 Autarquia do Ensino Superior de Garanhuns, Brazil E-mail: kaike41@hotmail.com

Priscila Honório Apolônio

ORCID: https://orcid.org/0000-0003-4820-868X Universidade Federal de Pernambuco, Brazil E-mail: priscilahonorio@aesga.edu.br Arnaldo Manoel Pereira Carneiro ORCID: https://orcid.org/0000-0002-4279-7156 Universidade Federal de Pernambuco, Brazil E-mail: arnaldo.carneiro@ufpe.br

Romilde Almeida de Oliveira

ORCID: https://orcid.org/0000-0002-6786-9080

Universidade Federal de Pernambuco, Brazil E-mail: romildealmeida@gmail.com

\begin{abstract}
The search for methods that provide savings greatly drives the search for alternatives when it comes to cost reduction. The obsession with aesthetics and cheaper alternatives for civil construction, can lead to unexpected and dangerous results. The reduction of the dimensions of the columns can be done consciously, always keeping in mind the compliance with normative standards combined with structural optimization. The objective of this work was to evaluate the efforts resulting from the reduction of the minimum dimensions beyond that established by NBR 6118 (ABNT, 2014) and compare with the considerations of NBR 15575 (ABNT, 2013) about a possible permission to reduce the minimum dimensions of columns. For this, the software MathCAD, Eberick and SAP2000 were used to implement the calculation and design methods of the columns. The variables evaluated were the steel area of columns with different cross sections, length of buckling and the necessary anchoring length that a beam would need to anchor in the columns. As a result, it was found that in relation to the steel area, the decrease in the section resulted in increases in the steel area. The buckling was not acceptable $(\lambda>140)$ with a cross-section column less than $19 \mathrm{~cm}$ for situations of double height up to $6 \mathrm{~m}$ in height, according to NBR 15575 cites. The criterion of anchoring the beam reinforcement in a column with section smaller than $14 \mathrm{~cm}$ was not feasible for all situations.
\end{abstract}


Keywords: Structural analysis; Columns; Performance; Reinforced concrete.

\begin{abstract}
Resumo
A procura de métodos que proporcionem economia impulsiona grandemente a busca de alternativas quando se trata de redução de custos. A obsessão por estética e alternativas mais baratas para a construção civil, podem levar a resultados não esperados e perigosos. A redução das dimensões dos pilares pode ser feita de maneira consciente, sempre tendo em mente o atendimento dos padrões normativos aliado à otimização estrutural. O objetivo desse trabalho foi avaliar os esforços decorrentes da diminuição das dimensões mínimas além da estabelecidas pela NBR 6118 (ABNT, 2014) e comparar com as considerações da NBR 15575 (ABNT, 2013) sobre uma possível permissão da redução das dimensões mínimas de pilares. Para isso foram utilizados os softwares MathCAD, Eberick e SAP2000 para implementar os métodos de cálculo e dimensionamento dos pilares. As variáveis avaliadas foram a área de aço de pilares com distintas seções transversais, comprimento de flambagem e o comprimento de ancoragem necessário que uma viga necessitaria para ancorar nos pilares. Como resultados, verificou-se que em relação à área de aço, a diminuição da seção acarretou em aumentos de área de aço. A flambagem não foi aceitável $(\lambda>140)$ com pilar de seção transversal inferior a $19 \mathrm{~cm}$ para situações de pé direito duplo com até $6 \mathrm{~m}$ de altura, conforme a NBR 15575 cita. $\mathrm{O}$ critério da ancoragem da armadura da viga num pilar com seção menor que $14 \mathrm{~cm}$ não foi viável para todas as situações.
\end{abstract}

Palavras-chave: Análise estrutural; Pilares; Desempenho; Concreto armado.

\title{
Resumen
}

La búsqueda de métodos que proporcionen ahorros impulsa en gran medida la búsqueda de alternativas cuando se trata de reducción de costos. La obsesión por la estética y las alternativas más económicas para la construcción civil, puede conducir a resultados inesperados y peligrosos. La reducción de las dimensiones de las columnas se puede realizar de forma consciente, siempre teniendo en cuenta el cumplimiento de los estándares normativos combinado con la optimización estructural. El objetivo de este trabajo fue evaluar los esfuerzos resultantes de la reducción de las dimensiones mínimas más allá de lo establecido por NBR 6118 (ABNT, 2014) y comparar con las consideraciones de NBR 15575 (ABNT, 2013) sobre un posible permiso para reducir el mínimo. dimensiones de pilares. Para ello, se utilizó el software MathCAD, Eberick y SAP2000 para implementar los métodos de cálculo y diseño de las columnas. Las variables evaluadas fueron el área de acero de los pilares con diferentes secciones transversales, el largo de pandeo y el largo de anclaje necesario que una viga necesitaría para anclar en los pilares. Como resultado, se encontró que, en relación al área de acero, la disminución en la sección resultó en incrementos en el área de acero. El pandeo no fue aceptable $(\lambda>140)$ con un pilar de sección inferior a $19 \mathrm{~cm}$ para situaciones de doble altura hasta $6 \mathrm{~m}$ de altura, según cita NBR 15575. El criterio de anclaje de la armadura de la viga en un pilar con una sección menor de $14 \mathrm{~cm}$ no era factible en todas las situaciones.

Palabras clave: Análisis estructural; Pilares; Rendimiento; Concreto armado.

\section{Introduction}

Concrete can be considered one of the scientific wonders of the modern world. Its discovery dates back to the middle of the 19th century, having received its first patent in 1878 in the USA and later in 1892 in Switzerland (Neville \& Brooks, 2010; Neville, 2016; Helene \& Andrade, 2017).

Based on technological advances, greater depth and knowledge of the main characteristics of concrete, it started to be produced and used on a large scale, in view of its wide applicability and also the possibility of having more durable structures (Mehta \& Monteiro, 1994; Sadati et al., 2016).

However, it was noticed a limitation in terms of application, considering that the concrete has an excellent performance in resisting the compression efforts, but it does not behave in the same way when it is requested in terms of tensile strength (Carvalho, 2014; Adamatti, 2016; Lazarini, 2019). As a rule, tensile strength corresponds to about 10\% of the compression value (Faria, 2017). To fill this gap, it was identified that the use of steel reinforcement with the concrete, made its execution viable, thus resisting the requested mechanical efforts (Mehta \& Monteiro, 2008; Araújo, 2010).

In view of the increased use of reinforced concrete structures, it was necessary to develop regulations that specifically deal with the minimum requirements for an element or the structure as a whole to meet the safety limits for habitability.

For this purpose, NBR 6118 (ABNT, 2014) establishes the minimum criteria that a reinforced concrete structure must have, from the dimensioning to the procedures to be adopted during the elaboration of the project. Concomitantly, NBR 15575 
(ABNT, 2013) ratifies the items in which they were not explained by NBR 6118 (ABNT, 2014) so that safety is in favor of everyone involved in the process.

The use of limits and normative processes and are not always taken into account, especially in small and mediumsized buildings. Sometimes are erroneously carry out activities without technical supervision by a person in charge of guaranteeing the global stability of the structure, as well as informing which procedures are necessary.

Based on the normative non-compliance to obey the established minimum limits, the buildings tend to have their useful life reduced, as the structures end up being made empirically, by professionals that do not have knowledge about dimensioning and also of concrete dosing, thus putting at risk the safety of all those who will enjoy that place.

As it is a process of general amplitude and a considered degree of complexity, when analyzed the whole without separating the parts, it is necessary to carry out a priori analyzes individually, in order to understand which factors will trigger the mechanical effects in the structure.

Therefore, one of the structural elements that suffers most from the constructions carried out incoherently without meeting the normative requirements are the columns, since they tend to be embedded in the $9 \mathrm{~cm}$ thick masonry, thus reducing its minimum size and also minimal steel area, putting the system at risk of possible collapse.

Based on this, the objective of this work was to evaluate the efforts resulting from the reduction of the minimum dimensions beyond that established by NBR 6118 (ABNT, 2014) and to compare with the considerations of NBR 15575 (ABNT, 2013) about a possible reduction of the dimensions minimum columns.

In order to achieve the objective of this work, the software MathCAD, SAP 2000 and Eberick (AltoQi, 2020) were used for modeling, dimensioning and analysis of reinforced concrete structures.

\section{Column Sizing Considerations}

Columns in reinforced concrete structures refers to the dates of the first buildings made with this structural system, being responsible for receiving and distributing the loads coming from the beams (loads received by slabs) to the foundations.

The columns are structural components that have as their main characteristic their arrangement in a vertical axis, with normal and compression efforts, according to NBR 6118 (ABNT, 2014).

It is worth mentioning that the columns have the need for minimum attendance for the dimensioning provided in the current regulations, considering that the non-attendance of them, may trigger structural, pathological and durability problems.

Several aspects must be taken into account when planning the design of a column. Among the many, the compliance with the Service Limit State (SLS) and the Ultimate Limit State (ULS). These are identified and used as security bases provided for in NBR 6118 (ABNT, 2014) as a temporal determination of the behavior of that structure over time.

As mentioned by NBR 6118 (ABNT, 2014), SLS is the state in which structural systems must act without interfering with the user's aesthetic and comfort functions. The stabilization in terms of comfort is not only sent to the inhabitants of the place, but also the machines and equipment that the given structure will support.

In terms of the scope of the ULS, which is a final stage of performance, the same standard deals that among the many events that must occur for its progression, the plastic or excessive rupture of the materials, the loss of the balance of the structure, the transformation of the structure in a hypostatic system, are preponderant factors for the characterization of this system. Therefore, the systems are dimensioned so as not to reach this limit state (Juliani \& Gomes, 2021).

In view of to provide the structure with greater security, NBR 6118 (ABNT, 2014) deals with mandatory use of weighting coefficients, both for strength of concrete and steel, these varying according to their combination factors (Table 1). 
Table 1. Weighting coefficients.

\begin{tabular}{lll}
\hline Combinations & Concrete & Steel \\
\hline Normal & 1,4 & 1,15 \\
Specials & 1,2 & 1,15 \\
Exceptional & 1,2 & 1,00 \\
\hline
\end{tabular}

Source: Adapted from NBR 6118 (ABNT, 2014).

As can be seen (Table 1), the coefficients are variants for both concrete and steel, considering mainly that the respective materials have very different manufacturing processes. While the concrete goes through all the elaboration of acquisition of aggregates, binders, additions and additives, so that later it has a homogeneous material; steel, in turn, is subjected to more industrialized processes, where the occurrence of failures during production is lower when compared to concrete, this resulting in a lower coefficient on the part of steel (Pereira Filho et al., 2017).

In view to provide security that is conducive to normal living conditions, sometimes the use of the most unfavorable conditions is indicated. However, it is worth mentioning that each building has a different context, and based on that, it is necessary to analyze the parts so that the precise dimensioning for each situation (Fusco, 2008; Cholfe \& Bonilha, 2018).

At the same time of determination of the weighting coefficients, the analysis as to the column layout will trigger changes in the calculation script, considering that the efforts that an intermediate column is considerably higher than those received by an end column and a corner column (Figure 1).

Figure 1. Intermediary, extremities and corner column.
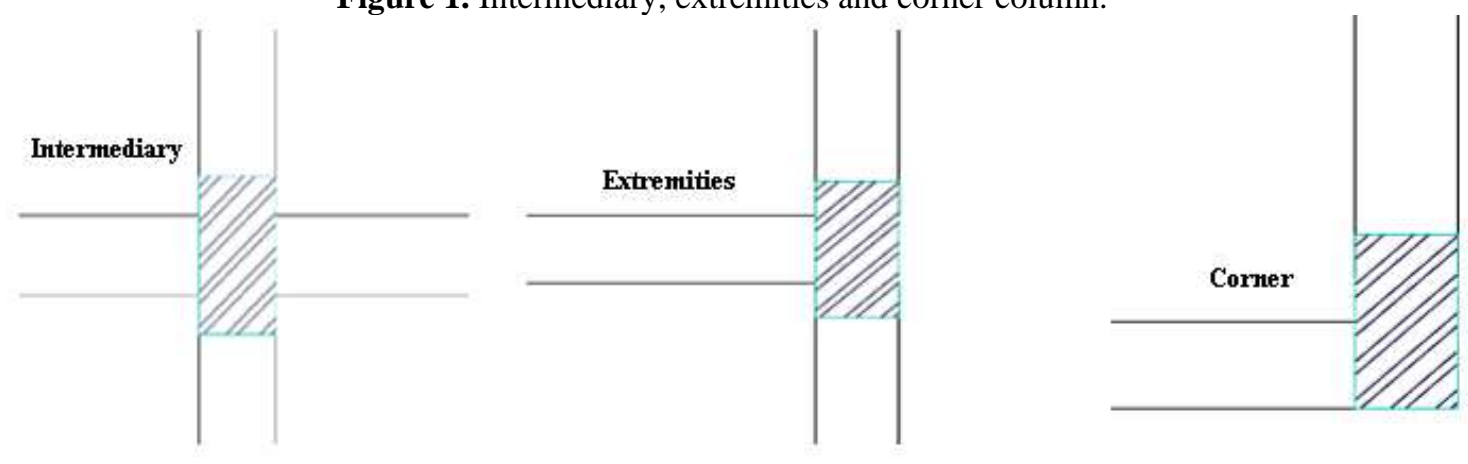

Source: Authors (2021).

Each type of column has preponderant characteristics, from the number of beams that exert stresses on them, to the arrangement and location in terms of performance, being increased to a greater or lesser extent depending on the local situation.

Even with the calculation scripts and analysis methods based on different principles, the anchoring concept remains unchanged for the application on columns, where it has the function of providing that the acting forces of compression or traction can be transferred to the concrete with the expected performance (Assis Júnior, 2005).

Regarding the dimensioning, materials and also the time in which the structures must withstand the calculated efforts, NBR 15575 (ABNT, 2013) makes several reservations. Among them, a premise causes a discomfort of understanding when analyzed in parallel to NBR 6118 (ABNT, 2014).

The standard NBR 15575 (ABNT, 2013), item 7.2.2.1, deals that for the dimensioning of single-storey houses and two-story houses, which do not exceed $6.0 \mathrm{~m}$ in height, considering the lowest level of foundation to the roof, there is no the need to meet the minimum dimensions provided for by NBR 6118 (ABNT, 2014) and other rules that govern calculation and structural security, with the exception of security and stability. 
Considerations based on this understanding generate discussions, considering that the same standard still indicates that the SLS and ULS cited mainly by NBR 6118 must be met (ABNT, 2014).

In view of this incongruity and analyzing the minimum dimensions established by NBR 6118 (ABNT, 2014), which provides as a minimum dimension for special conditions, $14 \mathrm{~cm}$ wide, respecting all imposed limits and dealing with the security of the building, the question arises whether it is possible to further reduce the column size, ensuring all structural safety criteria.

Based on a smaller facilitation for a column, one dimension has been used more, the $9 \mathrm{~cm}$ wide which is the same thickness as the $9 \mathrm{~cm}$ masonry block. This with a focus on taking advantage of forms, known as "muffled column".

In addition, the aesthetics defined in the architectural design also limits this, where it defines the finished wall $15 \mathrm{~cm}$ thick. Thus, this reduction ends up being classified as conducive to an inadequate / incomplete interpretation of NBR 15575 (ABNT, 2013) and ends up being carried out with a dimension smaller than that predicted by NBR 6118 (ABNT, 2014). In Figure 2, an example of $7 \times 17 \mathrm{~cm}$ column reinforcement can be identified.

Figure 2. Column with a dimension smaller than that provided by NBR 6118 (ABNT, 2018).

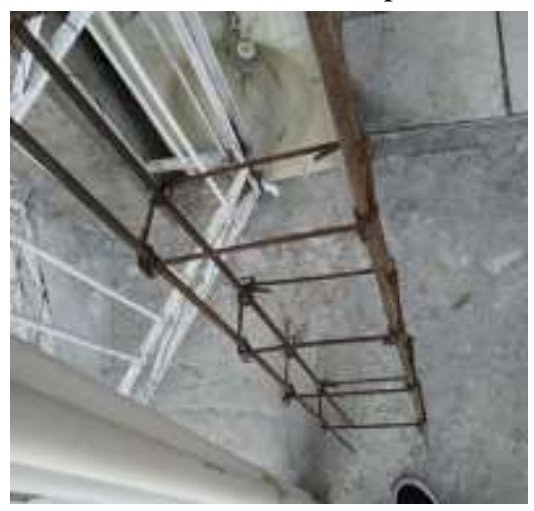

Source: Authors (2021).

As shown (Figure 2) and considering an Environmental Aggressiveness Class II (EAC-II), according to the nominal coverage established by NBR 6118 (ABNT, 2014), the column with stirrups in the dimensions of 7x17 cm, is found below the minimum dimension provided for in the same standard. In this case, only $1 \mathrm{~cm}$ of nominal coverage would remain, where the minimum would be $3 \mathrm{~cm}$, which goes against NBR 6118 (ABNT 2014), the performance standard itself.

This factor is due to the fact that when the concreting is carried out, the column will have a dimension of $9 \mathrm{~cm}$, when the minimum provided for by the standard is $14 \mathrm{~cm}$, still taking into account the coefficients of possible weightings. It should be noted that in the previous version NBR 6118, from 2003, the minimum dimension for the columns was $12 \mathrm{~cm}$, having already been changed in the later version to $14 \mathrm{~cm}$, thus realizing the need for its increase. And when $12 \mathrm{~cm}$ thick is used, the buckling and anchoring factors of a beam on a column, for example, need to be evaluated.

Thus, the need to understand what factors are being triggered by this lack of regulatory compliance is evident. One of the reasons that should be checked is in relation to the verification of slenderness, because as the dimensions of the columns are reduced, therefore, it happens that the column tends to become slenderer. To this end, Borges (1999) considers that slender columns, even though they have small eccentricities, have an increase in load and deformations due to flexion, thus causing uneven strain stresses. 


\section{Methodology}

In view of the need to propose methods and tools that make it possible to consciously reduce the minimum dimensions of structural elements, there is a need to carry out analyzes on the events that occurred in buildings in general context. This work is a case study, according Yin (2015).

Among such effects that cause adverse effects to safety and normal habitual conditions, the reduction of columns in an inconsequential way can generate damage and even collapse, thus putting the life of all users of these buildings at risk.

One of the reductions that has been most identified in recent years is in relation to the use of $9 \mathrm{~cm}$ thick columns, falling short of what NBR 6118 (ABNT, 2014), deals with as a minimum dimension to be obeyed. As a result, it is necessary to carry out checks on what such reductions may have on the columns, as well as on the structure as a whole.

For this, the Mathcad software was used to calculate the different types of columns, covering all parts of the design, leaving the basic design information to the user. Based on this, a simple frame (Figure 3) was adopted to indicate the location of the column to be dimensioned, it was modeled in the AltoQi Eberick software, in its Plena (AltoQi) version, 2020. In this case, the information collected was about analysis, dimensioning and detailing of structural elements.

Figure 3. Structural system in 3D.

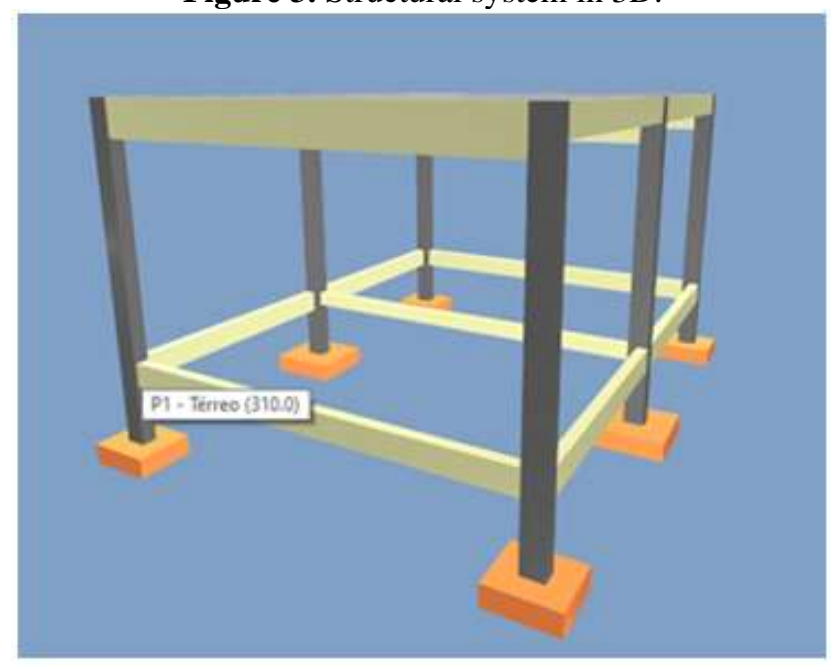

Source: Authors (2021).

As shown in the Figure 3, the analyzed column is the corner P1, with initial dimensions of $19 \times 26 \mathrm{~cm}$ and effective length of $3.10 \mathrm{~m}$. The V5 beam with dimensions of 19x55 cm in an effective span of $5.10 \mathrm{~m}$ and rests in the $\mathrm{y}$ direction of the P1 column, whereas the V4 beam has dimensions of $14 \times 30 \mathrm{~cm}$ with a $3.20 \mathrm{~m}$ span and rests on the $\mathrm{x}$ axis of the column P1.

For sizing the abutment, slenderness below 90 was adopted, the standard abutment method with approximate curvature. For abutment with slenderness greater than 90, standard abutment method with M, N, 1 / r diagrams were adopted.

Based on the need for software that would make it possible to perform somewhat complex calculations, SAP 2000 was used, and the curvature found is shown below (Figure 4). 
Figure 4. Moment curvature curve.

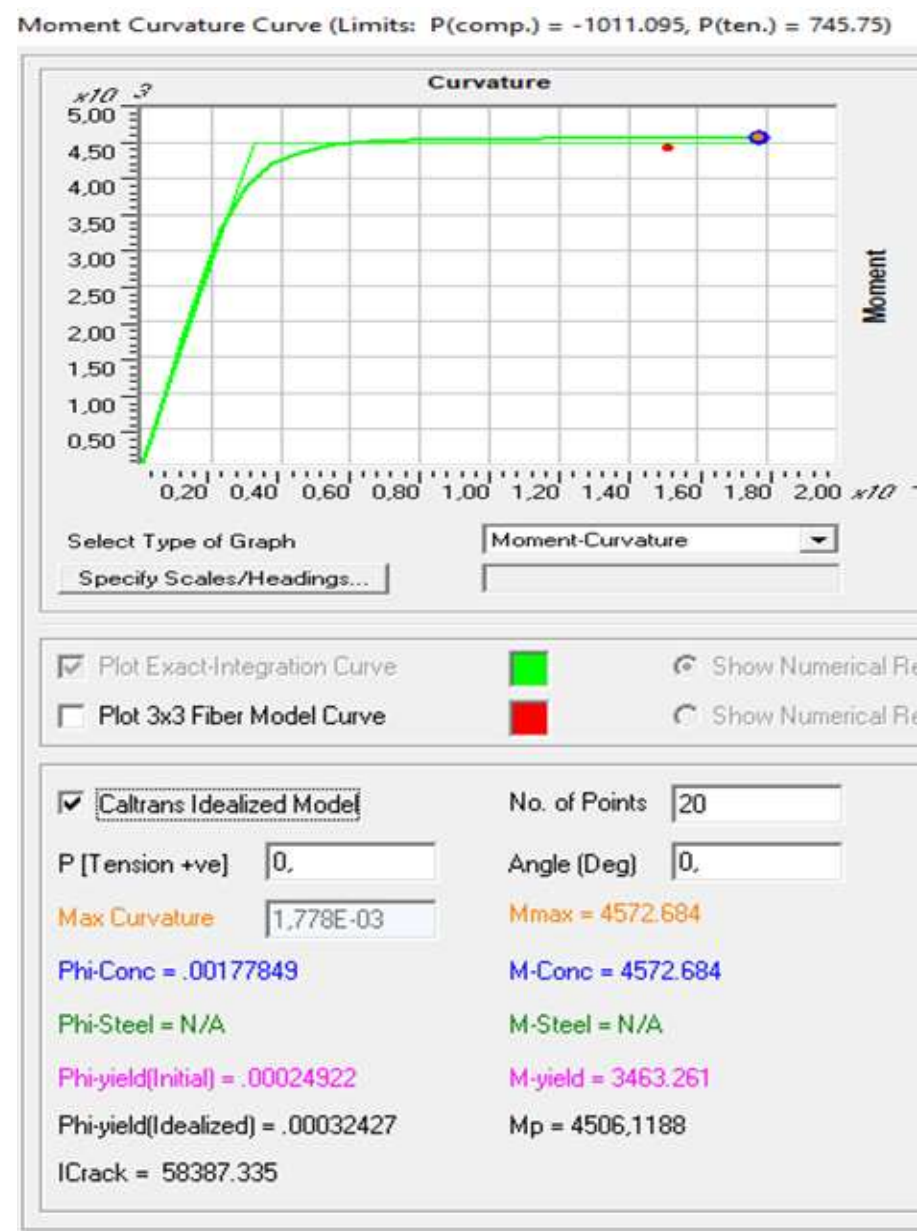

Source: Authors (2021).

As noted in the Figure 4, the calculation guide was established taking into account the maximum curvature and the respective factors on steel and concrete, thus having the property to continue the calculation safely and in compliance with the predicted limits.

\section{Results and Discussion}

The dimensioned column was a corner, as shown in Figure 3. It started with dimensions of 19x26 cm, the minimum required standard so that weighting coefficients for reduction to $14 \mathrm{~cm}$ are not used.

In order to identify possible changes that directly impact the final moments of calculation, steel area and also the number of bars to be used, calculations were made to understand the effects caused mainly by the variations in dimensions (Table 2). 
Table 2. Design results with different dimensions.

\begin{tabular}{ccccc}
\hline $\begin{array}{c}\text { Columns dimensions } \\
(\mathrm{cm})\end{array}$ & $\begin{array}{c}\text { Final Calculation Moments (kgf.m) } \\
\mathrm{x}\end{array}$ & $\begin{array}{c}\text { Cross-section steel area (As) } \\
\left(\mathrm{cm}^{2}\right)\end{array}$ & $\begin{array}{c}\text { No. of 10mm } \\
\text { bars }\end{array}$ \\
\hline $19 \times 26$ & 516,379 & 1229,895 & 3,043 & 4 \\
$14 \times 26$ & 419,291 & 1272,601 & 4,037 & 6 \\
$12 \times 26$ & 461.69 & 1247,066 & 4.998 & 8 \\
$12 \times 35$ & 489,073 & 2137,326 & 5,003 & 8 \\
$9 \times 19$ & 1401,86 & 679,554 & 12,642 & 18 \\
\hline
\end{tabular}

Source: Authors (2021).

Based on the results obtained (Table 2), the requesting moments are verified in both column directions. The y-axis has a greater demand considering that it is located in the region of greater slimness. In this respect, it appears that there is a tendency to increase its request for columns with smaller thicknesses. In the 9x19 cm section, the moment of greatest intensity occurred on the $\mathrm{x}$ axis. Regarding the steel areas, it was also found that, as the thickness was reduced, a larger steel area was necessary. The number of bars shown refers to the area of steel required. This increase also refers to a possible increase in the final costs of the elements.

Another important factor that stands out is in relation to the $12 \times 35 \mathrm{~cm}$ dimension column, which the $\mathrm{y}$-calculation moment has increased, even with the increase in the larger dimension, which was previously 26 and changed to $35 \mathrm{~cm}$. This is due to the rigidity properties, taking into account the opposite argument regarding the increase of only one dimension of the column, in this case, the highest value.

For the analysis of the steel area in the column, the following results were obtained (Table 3).

Table 3. Analysis of the steel areas of the columns.

\begin{tabular}{cccc}
\hline $\begin{array}{c}\text { Columns sections } \\
(\mathrm{cm})\end{array}$ & $\begin{array}{c}\text { Cross-section steel area (As) } \\
\left(\mathrm{cm}^{2}\right)\end{array}$ & $\begin{array}{c}\text { Variation in relation to the } \\
\text { previous As }(\%)\end{array}$ & $\begin{array}{c}\text { Variation in relation to the } \\
\text { initial As }(\%)\end{array}$ \\
\hline $19 \times 26$ & 3,043 & 0 & 0 \\
$14 \times 26$ & 4,037 & $32,67 \%$ & $32,67 \%$ \\
$12 \times 26$ & 4,998 & $23,80 \%$ & $64,25 \%$ \\
$12 \times 35$ & 5,003 & $0,10 \%$ & $64,41 \%$ \\
$9 \times 19$ & 12,642 & $152,69 \%$ & $315,45 \%$ \\
\hline
\end{tabular}

Source: Authors (2021).

Analyzing the data (Table 3), the steel area tends to increase according to the reduction in the dimensions of the column. Looking at the two sets of dimensions, $12 \times 26$ and $12 \times 35 \mathrm{~cm}$, where the concrete area of the second is greater than the first, there is a nearby steel area. This is due to the high loading of the V5 beam, and to the increase in the stiffness of the column in the y direction, increasing the flexion request and rendering the increase in the column dimension useless.

In the Figure 5, it is possible to identify the tendency to increase in relation to the steel area as the column dimension is reduced, thus causing a question about the feasibility in terms of using steel to reduce a structural element. 
Figure 5. Variation of cross-section steel area in relation to the initial As.

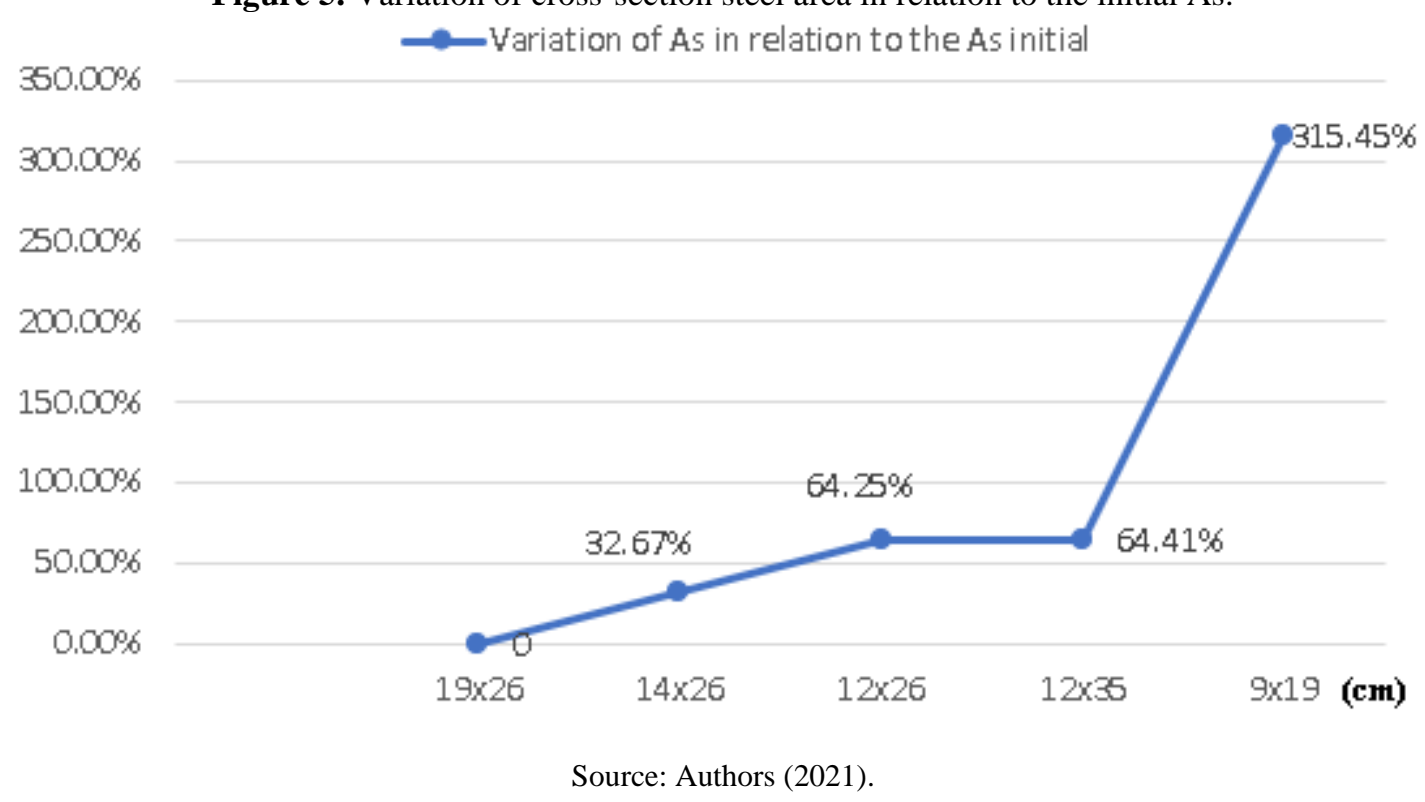

Based on the verification carried out in Figure 5, the variation in relation to the initial As is noticeable that the smaller the dimension, the greater the amount of steel required, reaching an increase of up to $315.45 \%$, generating an amount of bars considerable steel.

In addition to the steel area, it is also necessary to check the aspects regarding the minimum anchoring of the beam that rests on this pillar, because if it is not carried out without respecting the minimum dimensions, therefore, the structural set may be on the way to limits of use. due to anchorage deficiency (Table 4).

Table 4. Required anchoring lengths.

\begin{tabular}{ccccc}
\hline $\begin{array}{c}\text { Column size } \\
(\mathrm{cm})\end{array}$ & $\mathrm{x}($ straight $)$ & $\mathrm{y}$ Anchorage length required, two bars $(\mathrm{cm})$ & \\
\hline $19 \times 26$ & $10,00 \mathrm{~cm}$ & $22,453 \mathrm{~cm}$ & $6,4 \mathrm{~cm}$ & $15,717 \mathrm{~cm}$ \\
$14 \times 26$ & $10,00 \mathrm{~cm}$ & $22,453 \mathrm{~cm}$ & $6,4 \mathrm{~cm}$ & $15,717 \mathrm{~cm}$ \\
$12 \times 26$ & $10,00 \mathrm{~cm}$ & $22,453 \mathrm{~cm}$ & $6,4 \mathrm{~cm}$ & $15,717 \mathrm{~cm}$ \\
$12 \times 35$ & $10,00 \mathrm{~cm}$ & $22,453 \mathrm{~cm}$ & $6,4 \mathrm{~cm}$ & $15,717 \mathrm{~cm}$ \\
$9 \times 19$ & $10,00 \mathrm{~cm}$ & $14,969 \mathrm{~cm}$ & $6,4 \mathrm{~cm}$ & $15,717 \mathrm{~cm}$ \\
\hline
\end{tabular}

Source: Authors (2021).

It is possible to observe a predominance regarding the necessary anchorage length even with the variations in the dimensions of the columns. When analyzing the required anchorage length in $\mathrm{x}$, for it to be performed in a straight way, the minimum measure of two bars is $10 \mathrm{~cm}$ for all pillars with varying dimensions (Table 4). In the case of the pillar that is only 9 $\mathrm{cm}$, when the cover is discounted, there is not enough anchorage. The same is true for hook anchoring. In parallel to the analysis regarding the length in $\mathrm{y}$, also in a straight form, a tendency of 22,453 cm, until the 9x19 cm pillar, which require s $14,969 \mathrm{~cm}$ of anchoring, prevails. This respective reduction must already be analyzed with caution, mainly because it is the pillar with smaller dimensions in relation to the others calculated, and also, it is lower than the minimum dimensions, foreseen by NBR 6118 (ABNT, 6118).

For the cases of $\mathrm{x}$ and $\mathrm{y}$, in hook, the values consist in the predominance of 6.4 and $15.717 \mathrm{~cm}$, respectively, for all dimensions of columns analyzed. 
It is worth mentioning that the non-compliance with the minimum dimensions regarding the availability of steel for anchoring, may put at risk several factors of the structure, thus not making the analysis concise as a single structural element in terms of the overall analysis.

In view of this, it is necessary to have the available values of the lengths to carry out the analyzes regarding the predicted anchorages (Table 5).

Table 5. Available lengths.

\begin{tabular}{ccc}
\hline \multirow{2}{*}{ Column size } & \multicolumn{2}{c}{ Anchorage length required $(\mathrm{cm})$} \\
& $\mathrm{X}$ & $\mathrm{Y}$ \\
\hline $19 \times 26$ & 16,502 & 23,50 \\
$14 \times 26$ & 11,05 & 23,50 \\
$12 \times 26$ & 9,50 & 23,50 \\
$12 \times 35$ & 9,50 & 23,50 \\
$9 \times 19$ & 8,00 & 18,00 \\
\hline
\end{tabular}

Source: Authors (2021).

When analyzing the results obtained and comparing them (Tables 4 and 5), it appears that when using straight anchorage, only the pillars with dimensions 19x26 and 14x26 cm meet the lengths available and defined by NBR 6118 (ABNT, 2014). The other pillars do not meet the minimum requirements for straight anchoring and should be avoided. For anchoring with hook, the pillars with 9 and $12 \mathrm{~cm}$ also do not meet, since according to the minimum durability requirements in relation to EAC they would be in disagreement, as there is no minimum nominal coverage.

In a complementary and corroborative way to the treaties of NBR 15575 (ABNT, 2013) regarding the treaties for buildings up to $6.0 \mathrm{~m}$ in height, it should be evaluated with caution, as there are several architectural situations in which the pillars will have greater lengths of buckling, the example of single storey houses with double height, or first floor houses with double height. Therefore, it is necessary that the buckling length calculation is verified (Table 6).

Table 6. Available lengths and comparison with NBR 15575

\begin{tabular}{|c|c|c|c|c|}
\hline \multirow{3}{*}{$\begin{array}{l}\text { Abutment dimensions } \\
\qquad(\mathrm{cm})\end{array}$} & \multicolumn{4}{|c|}{ Comparison of the current case and the permission of NBR 15575} \\
\hline & \multicolumn{2}{|c|}{$3,00 \mathrm{~m}$} & \multicolumn{2}{|c|}{$6,00 \mathrm{~m}$} \\
\hline & Axis $\mathrm{x}$ & Axis y & Axis $\mathrm{x}$ & Axis y \\
\hline $19 \times 26$ & 56,52 & 41,30 & 109,39 & 79,94 \\
\hline $14 \times 26$ & 76,70 & 41,30 & 148,46 & 79,94 \\
\hline $12 \times 26$ & 89,49 & 41,30 & 173,20 & 79,94 \\
\hline $12 \times 35$ & 89,49 & 30,68 & 173,20 & 59,38 \\
\hline $9 \times 19$ & 119,32 & 56,52 & 230,94 & 109,39 \\
\hline
\end{tabular}

Source: Authors (2021).

When analyzing the buckling length of the samples (Table 6), it appears that only the $19 \mathrm{~cm}$ base column is acceptable, the others being unsuitable for calculation $(\lambda>140)$, being in disagreement with NBR 6118 (ABNT, 2014). Thus, one more situation that is at variance with the concrete standard is verified.

Therefore, a dimension smaller than $14 \mathrm{~cm}$ cannot be used. As the performance standard puts it, consideration should only be given to pillars with a cross-section smaller than $14 \mathrm{~cm}$ if all other requirements are met, without exception.

Thus, there is no need to speak about double interpretation, if all calculation parameters are verified, one cannot have a dimension smaller than that defined in the current concrete standard. It should be noted that it is vitally important that those responsible for the design care for safety conditions, even if these in some way, make it possible to reduce the dimensions of 
the structural elements. It should be noted that such reductions can be made, provided that they are made in a conscious manner, meeting all the safety criteria provided.

\section{Conclusion}

In the midst of a constructive temporality of constant evolutionary processes and the need to propose new executive forms and dimensioning calculations, it is necessary to meet all the normative proposals. When these are not obeyed, proof of calculation is required that such reductions or changes will not impact local security.

As a goal of this research, it was proved with the calculations why the standards always need updating, such as the comparison between the minimum dimensions of NBR 6118 (ABNT, 2014) with the 2003 version. In this case, it was observed that it was not it was feasible to use a pillar with those dimensions, as some parts of existing efforts were being ignored.

The reduction in cross-section leads to increased efforts. As expected, the results of dimensioning the 9x19 cm pillar, with the stirrups of $7 \times 17 \mathrm{~cm}$, obtained the highest results and made some situations such as anchoring and durability unfeasible, among the studied sections, making it unfeasible for any type of project.

It has also been proven that not always increasing the concrete area can lead to a decrease in the steel area, and this goes against several arguments by laypeople in the structural design context, who claim that the resistance is increased in this way, completely disregarding transfer of moments and increase the stiffness of the column in said direction, falling into the socalled stiffness trap.

Even with the building with a height less than $6.00 \mathrm{~m}$, the pillars following the precepts of NBR 15575 (ABNT, 2013) did not obtain acceptable results. It was not possible to perform the calculation due to the high buckling index (>140). Thus, situations with buckling length of up to $6.00 \mathrm{~m}$, it is not possible to use columns with a section smaller than that indicated by NBR 6118 (ABNT, 2014), as there are situations, such as those treated in this work, that do not allow use. In this case, NBR 6118 (ABNT, 2014) is sovereign. Thus, to guarantee the performance of any building, regardless of type and size, the minimum requirements for stability and structural safety must be maintained. This combined with durability criteria established in the performance standard.

Therefore, it is suggested that in the next update of NBR 15575 (ABNT, 2013), the text should be rectified in order to make it without dubious interpretation, or even make it without effect, to avoid better contextualization and conversation with NBR 6118 (ABNT, 2014), dealing with the design of reinforced concrete structures in a unique way.

As suggestions for future work, there is the possibility of experimental analysis to assess the anchoring system of a beam that overcomes a span of at least $5 \mathrm{~m}$, supported on a column with reduced cross section. Also, an experimental analysis of a $6 \mathrm{~m}$ high pillar simulating a double height, with reduced cross section.

\section{References}

Adamatti, D. S. (2016). Análise da eficiência de espaçadores no concreto armado: Impacto da corrosão por íons cloreto em diferentes condições de exposição. Dissertação de Mestrado. Repositório. Universidade Federal do Rio Grande do Sul. Retrieved from https://lume.ufrgs.br/handle/10183/149394

Araújo, J. M. (2010). Curso de concreto armado. (3a ed.), Dunas.

Assis Júnior, E. C. de. (2005). Análise numérica da ancoragem em ligações do tipo viga-pilar de extremidade. Dissertação de Mestrado. Repositório. Universidade de São Paulo. 10.11606/D.18.2005.tde-24042006-220951

Associação Brasileira de Normas Técnicas. (2003). NBR 6118. Projetos de estruturas de concreto - Procedimento.

Associação Brasileira de Normas Técnicas. (2014). NBR 6118. Projetos de estruturas de concreto - Procedimento.

Associação Brasileira de Normas Técnicas. (2013). NBR 15575. Edificações habitacionais - Desempenho. 
Research, Society and Development, v. 10, n. 5, e4710514575, 2021

(CC BY 4.0) | ISSN 2525-3409 | DOI: http://dx.doi.org/10.33448/rsd-v10i5.14575

Borges, A. C. L. (1999). Análise de pilares esbeltos de concreto armado solicitados a flexo-compressão oblíqua. Dissertação de Mestrado. Repositório. Universidade de São Paulo. 10.11606/D.18.2017.tde-06122017-144257

Carvalho, R. C. (2014). Cálculo e detalhamento de estruturas usuais de concreto armado. (4a ed.), Edufscar.

Cholfe, L; Bonilha, L. (2018). Concreto protendido na prática. (2a ed.), Oficina de Textos.

Faria, F. C. de. (2017). Otimização de Seções Poligonais de Concreto Armado Sujeitas à Flexão Composta. Dissertação de Mestrado. Repositório. Universidade Federal de Ouro Preto. https://www.repositorio.ufop.br/handle/123456789/8164

Fusco, P. B. (2008). Tecnologia do concreto estrutural: tópicos aplicados a componentes, durabilidades, resistência mecânica, corrosão e compressão. São Paulo: Pini.

Helene, P. \& Andrade, T. (2017). Materiais de Construção Civil e Princípios de Ciência e Engenharia dos Materiais. (3a ed.), IBRACON.

Juliani, M. A. \& Gomes, W. J. S. (2021). Optimal configuration of RC frames considering ultimate and serviceability limit state constraints. IBRACON Structures and Materials Journal. 2(14), 1-16.

Lazarini, P. R. S. (2019). Influência do concreto de alta resistência no dimensionamento de vigas: Deflexão em estados limites de serviço. Dissertação de mestrado. Repositório. Universidade Estadual de Maringá. http://www.pcv.uem.br/dissertacoes-1/copy_of_2-0-1-8

Mehta, P. K. \& Monteiro, P. J. M. (1994). Concreto: Microestrutura, Propriedades e Materiais. Pini.

Mehta, P. K. \& Monteiro, P. J. M. (2008). Concreto: Microestrutura, Propriedades e Materiais. (3a ed.), IBRACON.

Neville, A. M. (2016). Propriedades do concreto. (5a. ed.), Bookman.

Neville, A. M.; Brooks, J. J. (2010). Tecnologia do concreto. (2a ed.), Bookman.

Pereira Filho, A. P., Ballesteros, D. O., Magalhães, L. N, Ferrareto, J. A., Garcia, D. L., Lima, R. de S. \& Barros, B. (2017). Materiais de Construção Civil e Princípios de Ciência e Engenharia dos Materiais. (3a ed.), IBRACON.

Sadati, S., Arezoumandi, M., Khayat, K. \& Volz, J. S. (2016). Shear performance of reinforced concrete beams incorporating recycled concrete aggregate and high-volume fly ash. Journal of Cleaner Production. 115, 284-293. https://doi.org/10.1016/j.jclepro.2015.12.017

Yin R. K. (2015). Estudo de caso: planejamento e métodos. (5a ed.), Bookman. 